\title{
Financial Stress and Job Performance of Employees of a Government Agency in Negros Occidental
}

\author{
Meralie Mae B. Gualdrapa ${ }^{1}$ and Anabelle S. Palic ${ }^{2}$ \\ ${ }^{1}$ DPWH Negros Occidental 1st District Engineering Office, Talisay City, Philippines \\ 2University of Negros Occidental-Recoletos, Bacolod City, Philippines
}

\section{Article history \\ Submitted: 22 October 2020 \\ Revised: 4 November 2020 \\ Accepted: 10 November 2020 \\ Keywords \\ Business Administration \\ Financial Stress \\ Job Performance \\ Government Employees \\ Descriptive-Correlational \\ Negros Occidental}

stress and job performance.
Introduction. Financial stress is a condition that is becoming more predominant in society nowadays, especially among employees. There are more financial challenges among employees today, and these challenges are being reflected in the workplace's daily operations. Employees tend to bring financial problems into the workplace that affects their performance. The impact of financial stress has not been given considerable attention by human resource professionals in the government agencies in the Philippines. Thus, the paper determines the level of financial stress and job performance of employees of a Government Agency in Negros Occidental when grouped according to age, sex, family status, position level, estimated loan obligation, and district office. Also, it determines the relationship between financial

Methods. A descriptive-comparative and correlational research design were used to assess, compare, and contrast financial stress and job performance of employees of a government agency in Negros Occidental as well as to determine the relationship between the two variables. Total enumeration was used in determining the number of respondents of the study, a total of 157 permanent employees of a government agency. The data were gathered using a researcher-made instrument adopted from Parcia and Estimo (2017) for the level of financial stress and secondary data to assess the level of job performance. Mean, Standard Deviation, Mann Whitney U test, and Spearman rank correlation were used to analyze the data.

Results. The findings of the study revealed that the level of the financial stress of employees of a government agency in Negros Occidental as a whole is moderate regardless of age, sex, family status, position level, estimated loan obligation, and district office. Likewise, the level of employees' job performance is very satisfactory regardless of the demographics. Also, there is no significant difference in the level of financial stress when employees are grouped according to the demographics except for the estimated loan obligation. On the other hand, the level of job performance did not show a significant difference among the employees when grouped according to age, sex, family status, and district office. In contrast, there is a significant difference in the level of job performance when employees are grouped according to position level and estimated loan obligation. As to the relationship between the level of financial stress and job performance of a government agency's employees, the findings revealed a significant relationship.

Conclusion. Based on the findings, the researcher concluded that the level of financial stress experienced by the employees does not affect the level of their job performance, although a relationship exists between the two variables. Statistical results show that employees' level of financial stress is tolerable and has a lesser impact on the productivity of employees as what their performance reveals. This shows the resiliency of Filipino employees in a government agency. Despite the stress they experienced, their performance is not affected. Moreover, this means that financial stress can still be lowered, and job performance can be improved and reach a very high level.

Practical Value of the Paper. This study significantly contributes to the existing literature on the level of financial stress and job performance of employees of a government agency. The research-based information helped the HR office and the agency by increasing the employees' financial knowledge, skills, and confidence in dealing with their financial problems. Moreover, the findings of the study 
served as an "eye-opener" for employees in handling financial stress in order not to affect their performance. The results will also provide future researchers with the baseline data to work on other areas using different variables

\section{References}

Acedillo, M. (2018). Exploring the Personal Financial Management Practices of Teachers in the Countryside. The Countryside Development Research Journal, 6(1). Retrieved from http://cdrj.ssu.edu.ph/index.php/CDRJ/ article/view/82.

Bashir, U. \& Ramay, M. (2010). Impact of Stress on Employees Job Performance: A Study on the Banking Sector of Pakistan. International Journal of Marketing Studies, 2(1), 122-123.

Bonner, P. A. (2016). The impacts of financial stress on your employees. Benefits Magazine, 46-54. Retrieved from https://www.ifebp.org/inforequest/ifebp/0200354.pdf.

Caillier, J. (2010). Factors Affecting Job Performance in Public Agencies. Retrieved from https://www.researchgate. net/publication/261937686_Factors_Affecting_Job_Performance_in_Public_Agencis.

Chatterjee, S. \& Biswas, D. (2017). Determinants of Employee Performance: An Analytical Study with Reference to Public Power Generating Organizations of West Bengal. Indian Journal of Commerce \& Management Studies. ISSN: 2249-0310 EISSN: 2229-5674. http://dx.doi.org/10.18843/ijcms/v8i2/05.

Parcia, R. \& Estimo, E. (2017). Employees' Financial Literacy, Behavior, Stress, and Wellness. Journal of Human Resource Management, 5(5), 78-89. https://doi: 10.11648/j.jhrm.20170505.12.

Salleh, F., Dzulkifli, Z., Abdullah, W., \& Ariffin, N. (2011). The Effect of Motivation on Job Performance of State Government Employees in Malaysia. International Journal of Humanities and Social Science, 1(4).

Taft, M.K., Hosein, Z.Z., Mehrizi, S.M.T., \& Roshan, A. (2013). The relation between financial literacy, financial wellbeing, and financial concerns. International journal of business and management, 8(11), 63-75.

Vosloo, W., Fouché, J.P. \& Barnard R.J.J. (2014). The relationship between financial efficacy, satisfaction with remuneration, and personal financial well-being. International Business \& Economics Research Journal submitted for publication. Retrieved from https://repository.nwu.ac.za/bitstream/handle/10394/13455/ Vosloo_W.pdf.

Zaimah, R., Masud, J., Haron, S. A., Othman, M., Awang, A. H., \& Sarmila, M. D. (2013). Financial well-being: Financial ratio analysis of married public-sector workers in Malaysia. Asian Social Science, 9(14), 1-6. http://dx.doi. org/10.5539/ass.v9n14p1.

\section{Correspondence:}

Meralie Mae B. Gualdrapa [meralie02@gmail.com]

http://orcid.org/0000-0001-5548-2682 